\title{
Diskursus Perumusan Ideologi Sebagai Perbuatan Pidana dalam Rancangan Kitab Undang-Undang Hukum Pidana 2015*
}

\author{
Rocky Marbun** \\ DOI: https://doi.org/10.22304/pjih.v4n3.a6
}

\begin{abstract}
Abstrak
Reformasi Hukum Pidana pasca kemerdekaan Indonesia telah dimulai sejak 1963 terhadap Kitab Undang-Undang Hukum Pidana sebagai warisan dari kolonial Belanda. Semangat kemerdekaan menginginkan adanya reformasi, bukan hanya terhadap produk hukum yang masih bernuansa kolonialisme, namun juga pada cara pandang atau pola pikir dalam memandang permasalahan hukum. Salah satu pola pikir yang mendapat pengaruh warisan kolonialisme dalam mempertahankan rust en orde (menjaga keamanan dan ketertiban) adalah dengan memasukkan instrumen hukum guna mempertahankan kestabilan politik. Sehingga negara masih memandang urgenitas dari tindakan isolasir terhadap ideologi negara dengan melakukan pelarangan terhadap penyebaran ideologi Komunisme/Marxisme/Leninisme. Faktor terbesar dari perumusan pelarangan tersebut adalah pengalaman hitam bangsa Indonesia terhadap seseorang dan/atau kelompok organisasi yang mengimplementasikan ideologi tersebut dalam kegiatan-kegiatan yang membahayakan keutuhan bangsa. Akibatnya, terdapat ketidakjelasan dan ketidaktegasan dalam membedakan ideologi sebagai hasil olah akal budi yang menghasilkan ilmu pengetahuan dengan perbuatan sebagai perbuatan pidana dalam perumusan serta perancangan Pasal 212 ayat (2) jo. Pasal 219 ayat (2) Rancangan KUHP 2015 oleh pembentuk undang-undang.
\end{abstract}

Kata Kunci: ideologi, komunisme, KUHP, marxisme, RKUHP.

\section{Discussion of Ideology Formulation as Criminal Acts in the Draft of the Criminal Code 2015}

\begin{abstract}
The reform of Criminal Law in post-independence Indonesia has started since 1963 through the Criminal Code as a legacy of the Dutch colonial. The spirit of independence calls for a reform, not only against the law which still undeniably a product of colonialism, but also to the perspective or mindset of looking at legal issues. One mindset influenced by the legacy of colonialism in defense of rust en orde (maintain security and order) is to include legal instruments in order to maintain political stability. Thus, the state is still looking at the urgency of action against the state ideology isolation by banning the spread of the ideology of Communism/Marxism/Leninism. The biggest factor of the formulation of the ban was the dark experience of the Indonesian people against a person and/or group of organizations which implement that ideology in activities which endanger the integrity of the nation.
\end{abstract}

PADJADJARAN Jurnal IImu Hukum Volume 4 Nomor 3 Tahun 2017 [ISSN 2460-1543][e-ISSN 2442-9325]

* Tulisan ini pernah dipresentasikan dalam Focus Group Discussion dengan tema: Menelisik Pasal-Pasal Kejahatan Ideologi Negara dalam Rancangan Kitab Undang-Undang Hukum Pidana (RKUHP), yang diselenggarakan oleh Institute for Criminal Justice Reform (ICJR) dengan judul "Memahami Ideologi Sebagai Perbuatan Pidana", Hotel Morrisey, Jakarta, 29 September 2016. Artikel ini telah dikembangkan dari artikel aslinya.

** Dosen Fakultas Hukum Universitas Pancasila, Jl. Srenseng Sawah, Jagakarsa, Jakarta Selatan, Jl. Borobudur Np. 7, Jakarta Pusat, rocky.marbun08@gmail.com, S.H., M.H., Dr. (Universitas Jayabaya). 
Consequently, there is obscurity and uncertainty on the difference between ideology as an outcome of common sense which results in knowledge and ideology as a criminal action under the formulation and drafting of Article 212 para 2 jo. Article 219 para 2 of the Draft of the Criminal Code 2015 as drafted by the legislators.

Keywords: ideology, communism, criminal code, marxism, draft of the criminal code.

\section{A. Pendahuluan}

Hukum nasional merupakan suatu himpunan bagian hukum atau subsistem hukum yang saling berkaitan yang membentuk satu keseluruhan yang rumit atau kompleks tetapi merupakan satu kesatuan. ${ }^{1}$ Menurut Achmad Ali, sebagaimana mengutip pendapat Lawrence M. Friedmann, bahwa sistem hukum terdiri atas struktur hukum (structure), substansi/materi hukum (substance), dan budaya hukum (legal culture). ${ }^{2}$ Sehingga ketika berbicara pembaharuan sistem, khususnya peradilan pidana dalam kajian legal policy, tidak hanya kebijakan undang-undang, namun juga kebijakan yang berkaitan dengan struktur dan budaya hukum yang berkembang baik secara struktural maupun di masyarakat.

Pembaharuan hukum pidana tidak identik dengan pembaharuan Kitab Undang-Undang Hukum Pidana (KUHP). Pembaharuan hukum pidana lebih bersifat komprehensif daripada sekedar mengganti KUHP. Pembaharuan hukum pidana meliputi pembaharuan dalam bidang struktur, kultur, dan materi hukum. Sedangkan pembaharuan KUHP hanya berarti pembaharuan materi hukum pidana. ${ }^{3}$ Barda Nawawi Arief menyebutkan bahwa tidak ada artinya hukum pidana (KUHP) diganti/diperbaharui apabila tidak dipersiapkan atau tidak disertai dengan perubahan ilmu hukum pidananya. Dengan kata lain criminal law reform atau legal substance reform harus disertai pula dengan pembaharuan ilmu pengetahuan tentang hukum pidananya (legal/criminal science reform), bahkan harus disertai pula dengan pembaharuan budaya hukum masyarakat (legal culture reform) dan pembaharuan struktur atau perangkat hukumnya (legal structure reform). ${ }^{4}$ Sedangkan menurut Sudarto, pembaharuan hukum pidana yang menyeluruh itu harus meliputi pembaharuan hukum pidana material, hukum pidana formal, dan hukum pelaksanaan pidana. ${ }^{5}$

Perkembangan hukum pidana di Indonesia selalu menjadi hal yang menarik untuk dicermati, dikaji, dan dianalisis. Sebagai suatu bangsa yang merdeka, cita-cita memiliki hukum nasional merupakan suatu kewajaran. Oleh karena itu, terwujudnya

Kusnu Goesniadhie, Harmonisasi Hukum Dalam Perspektif Perundang-Undangan (Lex Spesialis Suatu Masalah), Surabaya: JP Books, 2006, hlm. 72.

Achmad Ali, Keterpurukan Hukum di Indonesia Penyebab dan Solusinya, Bogor: Ghalia Indonesia, 2005, hlm. 1. Ahmad Bahiej, "Pembaharuan Hukum Pidana Indonesia (Telaah atas Rancangan Kitab Undang-Undang Hukum Pidana Indonesia)", Makalah disampaikan pada kajian rutin Pusat Studi dan Konsultasi Hukum (PSKH) Fakultas Syari'ah IAIN Sunan Kalijaga Yogyakarta, tanggal 29 Desember 2003, hlm. 1.

4 Barda Nawawi Arief, Beberapa Aspek Kebijakan Penegakan dan Pengembangan Hukum Pidana, Bandung: Citra Aditya Bakti, 1998, hlm. 133.

5 Sudarto, Pembaharuan Hukum Pidana di Indonesia, Jakarta: Bina Cipta, 1986, hlm. 27. 
suatu hukum pidana nasional merefleksikan suatu keutuhan dari kemerdekaan itu sendiri.

Usaha untuk mewujudkan hal tersebut telah dirintis semenjak tahun 1963 dengan dimunculkannya draf Rancangan KUHP (RKUHP) pertama. Namun ironisnya, hingga saat ini cita-cita mulia tersebut tidak pernah terwujudkan. Perdebatan demi perdebatan selalu mewarnai usaha perumusan dari delik-delik yang bersifat nasional ataupun delik yang akan dinasionalkan. Permasalahan tersebut sangat erat kaitannya dengan pemahaman para perumus terhadap nilai-nilai sosial budaya bangsa Indonesia pada saat pembahasan RKUHP.

Pada waktu kitab hukum pidana Belanda (WvS.) yang merupakan cikal bakal dari KUHP Indonesia akan disiapkan, ilmu pada saat itu menganggap bahwa negaralah sebagai sumber yang terpenting, bahkan satu-satunya sumber hukum. Dalam bukunya Inleiding tot de studie van de wijsbegeerte des rechts, G.E. Langemeijer mengatakan bahwa hukum positif sekarang tidak dapat dipikirkan lain daripada bertolak dari negara karena sesungguhnya negara adalah nama yang diberikan untuk organisasi yang tertinggi untuk melaksanakan kekuasaan atas suatu daerah tertentu dan atas suatu kumpulan manusia tertentu. ${ }^{6}$

Perumusan hukum pidana nasional memang tidak akan pernah bisa dilepaskan dari bagaimana perwujudan politik hukum nasional Indonesia. Bukanlah hal yang aneh ataupun tabu untuk mengatakan bahwa pertarungan dalam ranah legislasi bukan saja pertarungan ilmu hukum, namun juga pertarungan kepentingan, khususnya kepentingan politik yang bersinggungan dengan kekuasaan. Sejarah pun pada akhirnya turut menentukan pergerakan kepentingan tersebut, yang menjadi 'adonan' dalam bungkus ilmu hukum. Oleh karena itu, tidaklah heran ketika ilmu hukum mendapat tempat sebagai konvergensi diversitas. Sehingga pengambilan suatu keputusan oleh pembentuk hukum, adalah suatu proses menimbangmenimbang dalam keseimbangan antara fleksibilitas, prediktabilitas, positivitas, koherensi, dan keadilan yang mengacu kepada cita hukum.

Salah satu persoalan pelik dan rentan dalam pembahasan adalah dikarenakan adanya kepentingan umum yang ditafsirkan sangat luas yaitu persoalan ideologi. Permasalahan ideologi bukan hanya sekedar permasalahan bagaimana melindungi ideologi negara yang sah, namun sarat dengan kepentingan pihak penguasa, karena sifat dari suatu ideologi sangat lentur dan multitafsir. Termasuk di dalamnya persoalan traumatik bangsa.

Di Indonesia, terdapat sejarah kelam pertumpahan darah antar anak bangsa sendiri terhadap suatu paham yaitu komunisme. Secara yuridis, Ketetapan Majelis Permusyawaratan Rakyat Sementara (TAP MPRS) No. XXV/MPRS/1966 tanggal 5 Juli 1966, langsung me-refer organisasi Partai Komunis Indonesia (PKI) sebagai

\footnotetext{
Supriyadi Widodo Eddyono dan Fajrimei A. Gofar, "Menelisik Pasal-Pasal Proteksi Negara dalam RUU-KUHP: Catatan Kritis terhadap Pasal-Pasal Tindak Pidana Ideologi, Penghinaan terhadap Martabat Presiden dan Wakil Presiden dan Penghinaan terhadap Pemerintah", Seri Position Paper Reformasi KUHP No. \#7/2007, Jakarta: Lembaga Studi dan Avokasi Masyarakat (ELSAM) dan Aliansi Nasional Reformasi KUHP, 2007, hlm. 8.
} 
partai politik yang terlarang dan Marxisme-Leninisme sebagai ideologi yang diklaim sebagai ideologi PKI dinyatakan sebagai ideologi terlarang. Ketetapan tersebut dikuatkan kembali dengan Ketetapan Majelis Permusyawaratan Rakyat (TAP MPR) No. I/MPR/2003 tanggal 7 Agustus 2003 tentang Peninjauan Terhadap Materi dan Status Hukum Ketetapan Majelis Permusyawaratan Rakyat Sementara dan Ketetapan Majelis Permusyawaratan Rakyat Republik Indonesia Tahun 1960 - 2002.

Dalam KUHP sendiri, tidak ditemukan perumusan delik yang berkaitan dengan ideologi tertentu, namun terdapat perumusan delik yang berkaitan dengan kejahatan terhadap keamanan negara. Sedangkan dalam sejarah perkembangan hukum pidana, Indonesia pernah memiliki Undang-Undang Nomor 11/PNPS/1963 tentang Pemberantasan Kegiatan Subversi (UU Pemberantasan Kegiatan Subversi), yang kemudian dicabut dengan Undang-Undang Nomor 26 Tahun 1999 tentang Pencabutan Undang-Undang Pemberantasan Kegiatan Subversi (UU 26/1999). Secara elegan dalam konsideran menimbang menegaskan bahwa UU Pemberantasan Kegiatan Subversi bertentangan dengan Hak Asasi Manusia (HAM) dan prinsip negara hukum.

Pada tahun yang sama diundangkan Undang-Undang Nomor 27 Tahun 1999 tentang Perubahan KUHP yang Berkaitan dengan Kejahatan Terhadap Keamanan Negara (UU 27/1999), yang mana ideologi yang dilarang dalam Pasal 1 ayat (1) huruf a UU Pemberantasan Kegiatan Subversi yang menyimpangi ideologi Pancasila sebagai Tindak Pidana Subversi, dicabut oleh UU 26/1999 dan dimunculkan kembali melalui UU 27/1999, dengan menambahkan Pasal 107a-107f ke dalam KUHP dengan landasan yuridis dalam Konsideran Menimbang huruf b menegaskan:

"bahwa Kitab Undang-undang Hukum Pidana terutama yang berkaitan dengan ketentuan mengenai kejahatan terhadap keamanan negara belum memberi landasan hukum yang kuat dalam usaha mempertahankan Negara Kesatuan Republik Indonesia yang berlandaskan Pancasila sebagai dasar negara." (cetak tebal oleh Penulis)

Dipertegas kembali pada Konsideran Menimbang huruf c dengan menyebutkan ideologi tertentu:

"bahwa paham dan ajaran Komunisme/Marxisme/Leninisme dalam praktek kehidupan politik dan kenegaraan menjelmakan diri dalam kegiatan-kegiatan yang bertentangan dengan asas-asas dan sendisendi kehidupan bangsa Indonesia yang bertuhan dan beragama serta telah terbukti membahayakan kelangsungan hidup bangsa Indonesia." (cetak tebal oleh Penulis)

UU 27/1999 bertujuan untuk melindungi ideologi Pancasila dan menunjuk langsung 'biang kerok' sejarah kelam Bangsa Indonesia yaitu ajaran Komunisme/ Marxisme/Leninisme. Di sisi lain, perumusan konsideran tersebut memunculkan permasalahan pemaknaan dalam konteks bahasa. Jika dicermati, perlindungan terhadap ideologi Pancasila terhadap hal apa? Terhadap ideologi Komunisme/ 
Marxisme/Leninisme sebagai suatu ajaran? Ataukah terhadap wujud/perbuatan hasil dari ideologi Komunisme/Marxisme/Leninisme?

Pembahasan dan pengkajian terhadap ideologi Komunisme/Marxisme/ Leninisme seolah-olah menjadi hal yang tabu untuk diperdebatkan. Entah karena diskursus-diskursus yang ada telah salah arah ataukah memang sengaja diarahkan? Persoalan ideologi Komunisme/Marxisme/Leninisme kembali mencuat ke permukaan yang diusung oleh penggerak HAM semenjak dimunculkan kembali dalam pasal-pasal yang ada dalam RKUHP versi 2015 melalui Pasal 219,, Pasal 220, ${ }^{8}$ dan Pasal 221. ${ }^{9}$ Perumusan delik-delik tersebut diasumsikan akan memunculkan tindakan-tindakan yang justru kembali marak dengan melanggar HAM seseorang dalam berekspresi.

Pertentangan terhadap dimunculkannya rumusan dalam pasal-pasal tersebut oleh karena didasarkan dari pengamatan sudut pandang yang berbeda. Bagi kaum pegiat HAM, redaksional rumusan tersebut dipandang sebagai bentuk kejahatan politik yang beranjak dari pendasaran atas keyakinannya. ${ }^{10}$ Seseorang tersebut, yang dianggap sebagai pelaku kejahatan, memiliki 'view' atas suatu bentuk negara yang

\footnotetext{
Pasal 219 Rancangan Kitab Undang-Undang Hukum Pidana (RKUHP) 2015:

“(1) Setiap orang yang secara melawan hukum di muka umum dengan lisan, tulisan, melalui media apapun, menyebarkan atau mengembangkan ajaran Komunisme/Marxisme/Leninisme dengan maksud mengubah atau mengganti Pancasila sebagai dasar negara, dipidana dengan pidana penjara paling lama 7 (tujuh) tahun.

(2) Tindak pidana sebagaimana dimaksud pada ayat (1) yang mengakibatkan:
a. terjadinya kerusuhan dalam masyarakat atau kerugian harta kekayaan, dipidana dengan pidana penjara paling lama 10 (sepuluh) tahun;
b. terjadinya kerusuhan dalam masyarakat yang mengakibatkan orang menderita luka berat dipidana dengan pidana penjara paling lama 12 (dua belas) tahun; atau
c. terjadinya kerusuhan dalam masyarakat yang mengakibatkan matinya orang dipidana dengan pidana penjara paling lama 15 (lima belas) tahun.

(3) Tidak dipidana orang yang melakukan kajian terhadap ajaran Komunisme/Marxisme-Leninisme dengan maksud dan tujuan semata-mata untuk kegiatan ilmiah."

8 Pasal 220 RKUHP 2015:

“Dipidana dengan pidana penjara paling lama 10 (sepuluh) tahun setiap orang yang:

a. mendirikan organisasi yang diketahui atau patut diduga keras menganut ajaran Komunisme/MarxismeLeninisme;

b. mengadakan hubungan dengan atau memberikan bantuan kepada atau menerima bantuan dari organisasi, baik di dalam maupun di luar negeri, yang diketahuinya berasaskan ajaran Komunisme/MarxismeLeninisme dengan maksud mengubah dasar negara atau menggulingkan pemerintah yang sah."

9 Pasal 221 RKUHP 2015:

“(1) Setiap orang yang secara melawan hukum di muka umum menyatakan keinginannya dengan lisan, tulisan, atau melalui media apa pun untuk meniadakan atau mengganti Pancasila sebagai dasar negara dipidana dengan pidana penjara paling lama 5 (lima) tahun.

(2) Tindak pidana sebagaimana dimaksud pada ayat (1) yang mengakibatkan:
a. terjadinya kerusuhan dalam masyarakat atau timbulnya kerugian harta kekayaan dipidana dengan pidana penjara paling lama 10 (sepuluh) tahun;
b. terjadinya kerusuhan dalam masyarakat yang mengakibatkan orang menderita luka berat dipidana dengan pidana penjara paling lama 12 (dua belas) tahun; atau
c. terjadinya kerusuhan dalam masyarakat yang mengakibatkan matinya orang dipidana dengan pidana penjara paling lama 15 (lima belas) tahun."
10 Jan Remmelink, Hukum Pidana: Komentar atas Pasal-Pasal Terpenting dari KUHP Belanda dan Padanannya dalam KUHP Indonesia, Jakarta: Gramedia, 2003, hlm. 74. 
ideal dan berkeinginan untuk mensosialisasikan kepada masyarakat luas. Demikian pula keterkaitannya dengan intensi dan tendensi dalam memperkuat kekuasaan politik dalam suatu rezim, di mana dalam praktik orde baru, Pancasila telah dimaknai sebagai ideologi.

Pada masa orde baru, Soeharto telah menganggap telah terjadi penyelewengan terhadap ideologi Pancasila sehingga kedudukan Pancasila sebagai ideologi harus dikembalikan, tetapi kenyataannya orde baru memonopoli pemaknaan Pancasila berdasarkan penerjemahannya sendiri dan menutup adanya pemaknaan lain. Setiap orang dipaksa mengikuti dan mengamini penerjemahannya. Soeharto menjadikan Pancasila sebagai alat untuk mengukuhkan dan menjaga kelanggengan kekuasaannya, maka Pancasila berubah dari sign of unity menjadi sign of authority. Pada masa orde baru, Pancasila akhirnya dipakai untuk menghantam pembangkangan terhadap Soeharto, sehingga akhirnya banyak pula pelanggaran HAM yang terjadi akibat pemaknaan Pancasila sebagai sign of authority tersebut. ${ }^{11}$

Perdebatan lain didasarkan kepada pandangan dari Abdul Hakim Garuda yang menjelaskan bunyi Pasal 212 RKUHP 2015 yang dirumuskan tidak secara ketat, dapat menjadi 'pasal karet' yang dapat digunakan secara membabi buta dan membuka diri terhadap berbagai interpretasi, terlebih lagi pasal tersebut tidak merinci dengan baik ajaran Komunisme/Marxisme-Leninisme seperti apa yang dilarang. Perumusan yang demikian sangat rentan terhadap pelanggaran HAM. ${ }^{12}$ Dengan demikian, setidaknya ada beberapa alasan pelarangan ideologi tersebut untuk tumbuh dan berkembang di Indonesia. yaitu:

1. Pengalaman masa lalu bangsa Indonesia (historis);

2. Upaya mempertahankan status quo orde baru;

3. Pemahaman terhadap ideologi sebagai bagian dari keyakinan; dan

4. Perlindungan hukum terhadap seseorang atas pengejawantahan norma yang terlalu abstrak.

Perbedaan sudut pandang demikianlah yang kemudian menimbulkan suatu paham atau ideologi tertentu, dalam hal ini adalah Komunisme/Marxisme/ Leninisme, dianggap sebagai suatu ancaman bagi ideologi Pancasila melalui pengalaman masa lalu. Di mana keyakinan seseorang terhadap ideologi tertentu tersebut diwujudkan dalam suatu bentuk kegiatan secara ekstrim dalam upayanya mengubah ideologi yang sah. Berdasarkan uraian-uraian tersebut, Penulis mencoba mengajukan rumusan masalah yang patut untuk dikaji secara ilmiah, yaitu: Bagaimanakah filosofi pemidanaan memandang perumusan delik terhadap suatu ideologi yang diklasifikasikan sebagai perbuatan pidana?

Supriyadi Widodo Eddyono dan Fajrimei A. Gofar, Loc.cit.

Abdul Hakim Garuda Nusantara, "Mengkritisi RUU KUHPidana Dalam Perspektif HAM", Makalah dalam Focus Groups Discussion Pembaharuan KUHP yang bertema 'Melihat Politik Kodifikasi dalam Rancangan KUHP', yang diselenggarakan oleh ELSAM, Hotel Ibis Tamarin, Jakarta, 28 September 2006, hlm. 50. 


\section{B. Esensi dari Perbuatan Pidana}

Van Hattum mengatakan dengan rumusan-rumusan delik tidak akan dapat diadakan gambaran yang sempurna mengenai aneka bentuk dari hidup ini. Hal tersebut dikarenakan rumusan-rumusan delik hanyalah fragmen yang dipisah-pisahkan dari hubungannya. Pembuat undang-undang tidak dapat berbuat lain selain hanya secara skema saja. Perbuatan-perbuatan yang termasuk dalam rumusan delik merupakan sekumpulan perbuatan yang pada umumnya dengan pidana. Karena rumusan fragmen dan skema maka di dalamnya termasuk perbuatan-perbuatan yang sebenarnya tidak di sana semestinya, oleh karena tidaklah merupakan perbuatan yang tercela atau tidak dibenarkan. ${ }^{13}$ Maka dapat dipergunakan ilustrasi yang dikemukakan oleh Simons dalam menjelaskan bahwa untuk menghilangkan sifat melawan hukum formil berdasarkan alasan-alasan pembenar, yang mana tidak hanya atas dasar pengaturan oleh hukum pidana yang merupakan alasanalasan pembenar yang bersifat umum dan khusus saja, tetapi harus ditetapkan atas dasar aturan dalam keseluruhan, jadi harus pula dengan memperhatikan normanorma dalam hukum perdata dan norma-norma lain yang menyebabkan perbuatan tertentu itu menjadi dibenarkan. ${ }^{14}$

Lebih tegas lagi sebagaimana diungkapkan oleh Binding bahwa hukum pidana menjaga dan mempertahankan norma-norma materiil secara fragmentaris. Lanjutnya, fungsi perlindungan hukum pidana demikian sebenarnya accessoir. Pandangan tersebut dikaitkan pada pemikiran bahwa hukum pidana hanya terdiri dari sanksi-sanksi dan bahwa norma-norma yang diacamkan pidana oleh hukum pidana, melainkan, misalnya, masuk ke dalam ranah hukum keperdataan atau hukum administrasi. ${ }^{15}$ Demikian pula sebagaimana dijelaskan oleh Enschede bahwa hukum pidana hanyalah rumusan delik yang menunjukan fragmen-fragmen dari norma-norma yang dapat dipidana, padahal khususnya rumusan delik mempunyai sifat sebagai suatu model yang mempunyai suatu aspek kenyataan yang kompleks dan model itu didefinisikan melalui tingkat abstraksi yang tinggi. ${ }^{16}$

Pandangan-pandangan demikian menurut Penulis merupakan suatu sinyalemen berkaitan mengenai paradigma apa yang menaungi Politik Hukum Pidana Indonesia sebagai bagian dari Politik Hukum Nasional. Berkaitan dengan hal tersebut, maka pembaharuan hukum pidana adalah suatu keniscayaan bilamana membatasi diri dengan mengisolasi pembaharuan terhadap ilmu hukum pidana itu sendiri. Walaupun Penulis cukup maklum, jika dikaitkan dengan Teori Konfigurasi Politik dari Mohlm. Mahfud MD, bahwa permasalahan ideologi menjadi momok bagi sebagian orang pada kalangan elite.

Namun demikian, hukum sebagai objek kajian dari ilmu hukum pidana memiliki tugas untuk mempelajari dan menjelaskan (interpretasi) hukum (tindak) pidana

Roeslan Saleh, Sifat Melawan Hukum Perbuatan Pidana, Jakarta: Aksara Baru, 1987, hlm. 17.

Ibid., hlm. 24.

Jan Remmelink, Pengantar Hukum Pidana Materiil 1, Yogyakarta: Maharsa Publishing, 2014, hlm. 7.

Komariah Emong Sapardjaja, Ajaran Sifat Melawan Hukum Materiel Dalam Hukum Pidana Indonesia, Bandung: Alumni, 2002, hIm. 4. 
yang berlaku pada suatu waktu dan negara (tempat) tertentu. Maka ilmu hukum mempelajari norma-norma dalam hubungannya dengan pemidanaan (konstruksi) dan kemudian menerapkan hukum pidana yang berlaku secara teratur dan berurutan (sistematika). Dengan perkataan lain, ilmu hukum pidana mengolah suatu tindak pidana yang sudah terjadi kemudian dihubungkan dengan penerapan hukum pidana yang berlaku. Selanjutnya dalam perkembangan, ilmu hukum pidana tidak hanya terbatas hanya mempelajari kenyataan-kenyataan tersebut, tetapi juga halhal yang bersangkut paut dengan hukum pidana yang bersifat filosofis, dogmatis, dan historis. ${ }^{17}$

Di dalam filsafat pemidanaan, pada prinsipnya terbagi ke dalam tiga aliran, yaitu: Aliran Klasik, Modern, dan Neo-klasik. Aliran Klasik muncul pertama kali pada Abad XVIII di Perancis. Aliran klasik merupakan bentuk perlawanan terhadap ancient regime yang arbitrary (sewenang-wenang) dan banyak menimbulkan ketidakpastian hukum. Sehingga Aliran Klasik menghendaki hukum pidana yang tersusun secara sistematis dan menitikberatkan kepada kepastian hukum. ${ }^{18}$ Dengan pandangannya yang indeterminisme mengenai kebebasan berkehendak manusia, aliran ini menitikberatkan kepada perbuatan dan tidak kepada orang yang melakukan tindak pidana. Sehingga perumusan undang-undang dan perbuatan yang melawan hukum merupakan titik sentral yang menjadi perhatian dari hukum pidana. ${ }^{19}$

Aliran Modern sering juga disebut Aliran Positif atau juga sering disebut sebagai Aliran Kriminologi karena dalam mencari sebab kejahatan menggunakan metode Ilmu Alam dan bermaksud untuk langsung mendekati dan mempengaruhi penjahat secara positif sejauh dia masih dapat diperbaiki. Menurut aliran ini, perbuatan seseorang tidak dapat dilihat secara abstrak dari sudut yuridis sematamata terlepas dari orang yang melakukan, tetapi harus dilihat secara konkret bahwa dalam kenyataannya perbuatan seseorang itu mempengaruhi watak pribadinya, faktor-faktor biologis maupun faktor lingkungan kemasyarakatannya. Jadi aliran ini bertitik tolak pada pandangan determinisme, dikarenakan manusia dipandang tidak mempunyai kebebasan kehendak tetapi dipengaruhi oleh watak dan lingkungannya, maka ia tidak dapat dipersalahkan atau dipertanggungjawabkan dan dipidana. Sehingga, aliran ini menolak pandangan adanya pembalasan berdasarkan kesalahan yang subjektif. ${ }^{20}$

Menurut Aliran Neo-klasik, pidana yang dihasilkan oleh aliran klasik terlalu berat dan merusak semangat kemanusiaan. Aliran Neo-klasik mulai mempertimbangkan kebutuhan adanya pembinaan individual dari pelaku tindak pidana. ${ }^{21}$ Ciri dari Aliran

E. Y. Kanter dan S. R. Sianturi, Asas-Asas Hukum Pidana di Indonesia dan Penerapannya, Jakarta: Storia Grafika, 2012, hlm. 33.

18 Muladi dan Barda Nawawi Arief, Teori-Teori dan Kebijakan Pidana, Bandung: Alumni, 2005, hlm. 25.

19 Djoko Prakoso, Masalah Pemberian Pidana Dalam Teori dan Praktek Peradilan, Jakarta: Ghalia Indonesia, 1984, hlm. 35.

20 Muladi dan Barda Nawawi Arief, Op.cit, hlm. 32.

21 Dwidja Priyatno, Kebijakan Legislatif tentang Sistem Pertanggungjawaban Pidana Korporasi di Indonesia, Bandung: CV. Utomo, 2004, hlm. 34-35 
Neo-klasik yang relevan dengan prinsip individualisasi pidana adalah modifikasi dari doktrin kebebasan berkehendak dan doktrin pertanggungjawaban pidana. Beberapa modifikasinya antara lain, diterima berlakunya keadaan-keadaan yang meringankan (mitigating circumstances) baik fisikal, lingkungan maupun mental, termasuk keadaan-keadaan lain yang dapat mempengaruhi pengetahuan dan niat seseorang pada waktu terjadinya kejahatan. ${ }^{22}$ Berdasarkan hal tersebut, sehingga permasalahan pokok dalam Hukum Pidana selalu berkutat kepada permasalahan berupa tindak pidana (strafbaarfeit/criminal act/actus reus), kesalahan (schuld/ guilt/mens rea), dan pidana (straf/punishment/poena).

\section{Paradigma IImu Hukum Indonesia}

Ilmuwan hukum dalam kegiatan ilmiahnya akan bertolak dari sejumlah asumsi dan bekerja dalam kerangka dasar umum (general basic framework). Hal ini selanjutnya memungkinkan munculnya diskursus (komunikasi dan diskusi secara rasional) dalam lingkungan ilmuwan hukum. Perangkat asumsi dan kerangka umum tersebut pada masa kini dapat disebut 'paradigma' dalam ilmu hukum. ${ }^{23}$ Maka pertanyaannya adalah paradigma apa yang digunakan oleh ilmuwan hukum (akademisi hukum dan praktisi hukum) di Indonesia?

Dua paradigma terbesar, yaitu paradigma filsafat hukum alam dan positivisme hukum, selalu memperdebatkan makna dari keadilan. Hukum alam memaknai keadilan melalui refleksi kefilsafatan, sehingga memunculkan berbagai definisi. Sedangkan positivisme hukum telah mengistirahatkan kontribusi filsafat karena dianggap sebagai sesuatu yang memunculkan ketidakpastian. Perspektif dari kaum positivis adalah beranjak dari peraturan tertulis, yakni sepanjang hal-hal yang dipermasalahkan telah ditentukan oleh undang-undang, maka undang-undang-lah yang dimaknai sebagai sesuatu yang adil. Permasalahannya adalah ketika Indonesia menjadi ajang pertarungan tiga paradigma, yaitu: paradigma filsafat sejarah; hukum alam; dan positivisme hukum. Secara historis, Indonesia mengalami tiga fase perkembangan hukum, yaitu fase pra-kolonialisme, fase kolonialisme, dan fase kemerdekaan.

Pada fase kemerdekaan nampak sekali perdebatan antara ahli hukum pro status quo dengan ahli hukum yang menginginkan perubahan paradigma dalam berhukum. Sehingga muncul jalan tengah bagi semua pihak yaitu Pasal II Aturan Peralihan Undang-Undang Dasar 1945 (UUD 1945) pra-amandemen yang didasarkan kepada asas konkordansi. Akibatnya adalah dalam kehidupan hukum di Indonesia masih menggunakan paradigma yang telah diajarkan dan ditanamkan oleh bangsa kolonial selama beratus-ratus tahun yaitu paradigma positivisme hukum dan sistem hukum civil law dari Keluarga Hukum Eropa Kontinental.

Demikian pula CFG. Sunaryati Hartono menjelaskan setelah Proklamasi Kemerdekaan 17 Agustus dan berlakunya UUD 1945, sistem hukum Indonesia

22 M. Sholehuddin, Sistem Sanksi Dalam Hukum Pidana: Ide Dasar Double Track System \& Implementasinya, Jakarta: RajaGrafindo Persada, 2003, hlm. 73.

23 Bernard Arief Sidharta, IImu Hukum Indonesia: Upaya Pengembangan Ilmu Hukum Sistematik Yang Responsif Terhadap Perubahan Masyarakat, Yogyakarta: Genta Publishing, 2013, hlm. 71. 
yang semula terbentuk dikarenakan pengaturan yang didasarkan kepada Indische Staatsregeling (I.S) digantikan oleh Pancasila dan UUD 1945 sebagai sumber segala sumber hukum. Namun sebagai akibat Aturan Peralihan Pasal II dalam UUD 1945, maka masih berlaku juga bagian-bagian dari hukum kolonial, dengan beberapa penyesuaian. ${ }^{24}$

Paradigma hukum mengalami stagnasi yang mana positivisme hukum sebagai suatu paradigma tidak pernah mengalami apa yang disebut Thomas Kuhn sebagai 'anomali'. Artinya, positivisme hukum terus bertahan dalam kemapanan (normal science) dari generasi ke generasi dalam bentuk praktik hukum. ${ }^{25}$ Walaupun memang wacana yang digulirkan dalam Seminar Hukum Nasional ke-II Tahun 1968 tersebut, menurut Penulis, turut diilhami oleh pendapat dari Moeljatno yang diutarakan dalam makalahnya sebagai pembahas Konsep Buku I KUHP, Beliau mempertanyakan konsep dari pembentukan sistem hukum pidana melalui makalah yang berjudul 'Atas Dasar atau Asas-Asas Apakah Hendaknya Hukum Pidana Kita Dibangun?'. ${ }^{26}$ Demikian pula ditegaskan dalam Seminar Hukum Nasional ke II Tahun 1968, yaitu sebagai berikut: "UUD 1945 hanyalah boleh dilaksanakan atas dasar Pancasila. Pelaksanaan UUD 1945 yang berlawanan dengan semangat dan jiwa Pancasila berarti manipulasi konstitusi dan penghianatan terhadap Pancasila". ${ }^{27}$

Berkaitan dengan uraian di atas, guna menentukan paradigma dalam berhukum yang sesuai di Indonesia, hendaknya mengacu pada pembentukan nilai-nilai dalam hukum itu sendiri. Sebagaimana ditegaskan oleh Jan Gijssels dan Mark van Hoecke, hukum itu merupakan suatu pencerminan dari suatu peradaban (beschaving). ${ }^{28}$ Dengan demikian, Penulis berkeyakinan bahwa dalam berhukum di Indonesia, cara pandang dan cara berpikir dalam politik hukum pidana wajib menggunakan Pancasila sebagai paradigma ilmu hukum Indonesia.

Sebagai suatu ideologi, Pancasila telah ditetapkan sebagai ideologi terbuka. Menurut Jimly Asshiddiqie, ideologi terbuka hanya berisi orientasi dasar, sedangkan penerjemahannya ke dalam tujuan-tujuan dan norma-norma sosial-politik selalu dapat dipertanyakan dan disesuaikan dengan nilai dan prinsip moral yang berkembang di masyarakat. Operasional cita-cita yang akan dicapai tidak dapat ditentukan secara a priori, melainkan harus disepakati secara demokratis. Dengan sendirinya ideologi terbuka bersifat inklusif, tidak totaliter, dan tidak dapat dipakai melegitimasi kekuasaan sekelompok orang. Ideologi terbuka hanya dapat ada dan mengada dalam sistem yang demokratis. ${ }^{29}$

24 CFG. Sunaryati Hartono, Politik Hukum Menuju Satu Sistem Hukum Nasional, Bandung: Alumni, 1991, hlm. 61.

25 Widodo Dwi Putro, Kritik Terhadap Paradigma Positivisme Hukum, Yogyakarta: Genta Publishing, 2011, hlm. 3.

26 Barda Nawawi Arief, RUU KUHP Baru: Sebuah Restrukturisasi/Rekonstruksi Sistem Hukum Pidana Indonesia, Semarang: Badan Penerbit Universitas Diponegoro (Undip), 2012, hlm. 8.

27 Barda Nawawi Arief, Pembangunan Sistem Hukum Nasional (Indonesia), Semarang: Badan Penerbit Undip, 2012, hlm. 13.

28 Jan Gijssels dan Mark van Hoecke, "Apakah Teori Hukum Itu?", diterjemahkan oleh Bernard Arief Sidharta, Penerbitan Tidak Berkala Nomor 3, Seri Dasar-Dasar Ilmu Hukum Nomor 3, Bandung: Laboratorium Hukum Fakultas Hukum Universitas Katolik Parahyangan, 2001, hlm. 16.

29 Jimly Asshiddiqie, "Ideologi, Pancasila, dan...", Op.cit., hlm. 3. 
Filasafat Pancasila sendiri mempunyai cara-cara spesifik dalam menerima dan mengolah pengaruh ideologi dan filsafat asing, yakni metode 'ekletis-inkorporasi', yaitu pengolahan nilai-nilai dari luar menjadi milik bangsa Indonesia dengan tetap berdasarkan pada asas Pancasila. Sesungguhnya proses seperti ini sudah berlangsung sejak awal abad XIX dengan dikenalinya konsep-konsep modern seperti humanisme, demokrasi, nasionalisme, dan sosialisme. Pancasila itu sendiri yang dirumuskan definitif sejak tanggal 1 Juni, 22 Juni, dan 18 Agustus 1945 tidak nihil dari pengaruh ideologi luar, terbukti dari sila-silanya yang mengadopsi konsep-konsep modern. ${ }^{30}$

Sebagaimana diungkapkan oleh Haryono bahwa sebagai produk pemikiran yang luhur, Pancasila selain digali dari bukti budaya nusantara juga diperkaya oleh jiwa dan semangat luhur budaya universal. Prinsip-prinsip yang ada di dalam Pancasila tidak semuanya berasal dari asing. Para pendiri bangsa mengolah kembali warisan Nusantara dan memperkayanya dengan warisan dunia sehingga muncul suatu rumusan Pancasila yang sangat cerdas dan visioner. Dari perpaduan budaya global dan warisan budaya yang luhur itulah berhasil dirumuskan Pancasila sehingga suatu dasar negara sekaligus pandangan hidup. ${ }^{31}$

\section{Hegemoni Positivisme Hukum dalam Sistem Peradilan Pidana}

Hukum selalu diperkenalkan kepada calon Sarjana Hukum sebagai suatu sistem peraturan perundang-undangan yang tersusun secara logis dan konsisten. Di samping pengertian logis dan konsisten ini biasanya masih ditambahkan lagi pengertian sistem yang tertutup, oleh karena hakikatnya memang yang dipelajari itu hanyalah di dalam kerangka peraturan-peraturan hukum positif saja. IImu pengetahuan hukum itu sebagai ilmu yang deduktif. Tujuannya adalah untuk menerapkan peraturanperaturan hukum itu pada kejadian-kejadian sehari-hari di dalam masyarakat. ${ }^{32}$

Uraian di atas pada hakikatnya merupakan pembahasan mengenai 'penegakan hukum', yang mana secara konsepsional arti penegakan hukum terletak pada kegiatan menyerasikan hubungan nilai-nilai yang terjabarkan di dalam kaidahkaidah yang mantap dan mengejawantah sikap tindak sebagai rangkaian penjabaran nilai tahap akhir untuk menciptakan, memelihara, dan mempertahankan kedamaian pergaulan hidup. ${ }^{33}$ Karena itu, pada gilirannya, implementasi aturan-aturan hukum oleh pengambil putusan yang otoritatif menuntut fleksibilitas. Jadi di satu pihak, pengambil putusan harus mengadaptasi aturan hukum pada situasi-situasi yang wujud konkret persisnya tidak mungkin diantisipasi atau dibayangkan oleh pembentuk hukum (pembentuk undang-undang), tetapi di lain pihak harus tetap prediktabel (dapat diprediksi).

Dalam ketegangan antara stabilitas dan flesibilitas itu, implementasi hukum harus selalu mewujudkan kompromi antara prediktabilitas dan keadilan, dengan

30 Slamet Sutrisno, Filsafat dan Ideologi Pancasila, Yogyakarta: Penerbit Andi, 2006, hlm. 5.

31 Haryono, Ideologi Pancasila: Roh Progresif Nasionalisme Indonesia, Malang: Instrans Publishing, 2014, hlm. 131.

32 Satijipto Rahardjo, Hukum, Masyarakat, dan Pembangunan, Bandung: Alumni, 1980, hlm. 1-2.

33 Soerjono Soekanto, Faktor-Faktor yang Mempengaruhi Penegakan Hukum, Jakarta: Rajawali Press, 2012, hlm. 5. 
menggunakan metode interpretasi dan konstruksi yuridis yang tepat dengan selalu mengacu pada cita hukum. Maka pengambil putusan akan terdorong untuk mempertimbangkan 'policy' dan aspek teleologikal yang melandasi aturan hukum terkait. $^{34}$ Oleh karena itu, pengambilan keputusan dalam proses penegakan hukum, tidak hanya didasarkan kepada ilmu hukum an sich, namun pada tataran sistematisasi eksternal ilmu hukum turut pula mengadopsi strategi ilmu sosial, sehingga ilmu hukum menjadi lebih relevan dan dinamis. Hal tersebut adalah suatu kewajaran, pada hakikinya tugas dari ilmu hukum adalah memberikan solusi alternatif penyelesaian sengketa terhadap permasalahan hukum yang tidak mungkin dipungkiri bahwa masyarakatlah menjadi tempat akhir bekerjanya ilmu hukum.

Hegemoni paradigma positivisme hukum merasuk hingga ke sumsum dari komponen Sistem Peradilan Pidana, yaitu Kepolisian Republik Indonesia (Polri), melalui jabatan (ambt) yang dinamakan penyidik dan penyelidik Polri, bahkan menjangkit pula kepada lembaga Kejaksaan dan Mahkamah Agung. Dalam tulisan ini, Penulis hanya mengambil salah satu contoh dari institusi yang paling dekat dengan proses penegakan hukum, yaitu Polri.

Beberapa mata kuliah dalam pendidikan Polri mengadopsi metode penyelesaian sengketa dan metode pengambilan keputusan melalui ilmu-ilmu alamiah sebagai metode tunggal, misalnya analitical hierarchy process (AHP) dan analisis strengthweakness-opportunities-threats (SWOT), dan scenario learning. Pada konsep AHP, suatu metode pengambilan keputusan yang dikembangkan oleh Thomas L. Saaty, mendasarkan konse kepada metode matematika untuk menyelesaikan permasalahan. ${ }^{35} \mathrm{Hal}$ ini merupakan penerapan ilmu sains dalam kehidupan manusia. Polri secara sadar menggunakan metode penyelesaian sengketa dan metode pengambilan keputusan yang didasarkan kepada ilmu-ilmu alamiah (naturswissenschaften) sebagaimana yang diinginkan oleh filsafat Cartesian dan filsafat positivisme yang menjadi sumber utama dalam paradigma positivisme hukum.

Wilhelm Dilthey yang menjelaskan semua ilmu pengetahuan tentang manusia tidak pernah bersifat statis. Wilhelm Dilthey membedakan dengan tajam antara naturwissenschaften dengan geisteswissenschaften. Pada geisteswissenschaften tidak dapat diterapkan metode-metode ilmiah seperti pada naturwissenschaften, karena geisteswissenschaften berhubungan dengan hidup manusia. ${ }^{36}$ Metode yang tepat dalam geisteswissenschaften adalah 'memahami', bukan 'mengetahui'. Usaha-usaha untuk mengempiriskan ilmu hukum menjadikan ilmu hukum bebas nilai, netral, dan subjektif-individual. Pemahaman terhadap ilmu hukum demikian jelas tidak memiliki korelasi dengan paradigma yang dimiliki oleh Indonesia. Bangsa Indonesia menganut cara pandang integralistik sebagai lawan dari cara pandangan individualistik. Cara pandangan integralistik Indonesia tersebut disebut

34 Bernard Arief Sidharta, Ilmu Hukum Indonesia..., Op.cit., hlm. 23.

35 Thomas L. Saaty, "Relative Measurement and Its Generalization Decison Making: Why Pairwise Comparations are Central in Mathematics for the Measurement of Intangible Factors: The Analytic Hierarchy/Network Process", Rec. R. Acad. Cien Serie A. Mat, Vol. 102 (2), 2008, hlm. 252.

36 E. Sumaryono, Hermeneutik: Sebuah Metode Filsafat, Yogyakarta: Kanisius, 1999, hlm. 50. 
sebagai asas kekeluargaan, yang memandang dalam hubungannya antara individu dan masyarakat, maka masyarakat yang diutamakan namun harkat dan martabat manusia tetap dihargai. ${ }^{37}$

Paradigma demikian yang terpola dalam ranah Polri, yang pada akhirnya mematikan daya nalar dan penalaran hukum dari penyidik Polri dalam memahami pasal-pasal pidana. Sebagai contoh: seberapa jauhkah pemahaman para penegak hukum terhadap ajaran sifat melawan hukum (wederrechtelijkeheid) yang termuat dalam Pasal 219 RKUHP 2015? Seberapa jauh pemahaman filsafat pemidanaan yang berkembang saat ini? Memang tidak bisa dipungkiri bahwa daya nalar dan penalaran hukum tersebut pula bergantung kepada teknik dari perumusan suatu perundangundangan pidana. Karena lagi-lagi, dalam memahami teks otoritatif membutuhkan kemampuan bahasa hukum yang mapan.

Kita harus kembali pada pengalaman orisinal dari para penulis teks dengan maksud untuk menemukan 'kunci' makna kata-kata atau ungkapan. Kita mengungkapkan diri kita sendiri melalui bahasa sehari-hari, tetapi seringkali kita dapat meragukan sendiri apakah pengalaman-pengalaman mental atau pikiran yang ada di balik bahasa benar-benar sudah terungkapkan secara menyakinkan. Seperti halnya ketika Belanda dalam menyusun dan merumuskan pasal-pasal pidana dalam wetboek van strafrecht meminta bantuan dari Sarjana IImu Bahasa Belanda kenamaan yaitu Prof. M. De Vries. ${ }^{38}$ Oleh karena itu, jika seorang melakukan interpretasi terhadap pasal-pasal saat ini yang dibuat pada masa lalu, maka ia akan berhadapan dengan jangka waktu, sikap mental, dan paradigma serta kondisi pada saat pasal-pasal tersebut dirumuskan.

Oleh karenanya, kesulitan-kesulitan tersebut akan kembali muncul manakala pembaharuan hukum pidana seringkali tidak mengindahkan perbaikan kualitas pendidikan ilmu hukum di Indonesia, khususnya terhadap institusi penegak hukum. Pasal-pasal tersebut akan menjadi 'karet' manakala si penafsir tidak memahami esensi dari suatu ideologi sebagai hasil dari gagasan olah pemikiran seseorang. Ketidakpahaman suatu pasal pidana, sebagai suatu hubungan terfragmentasi, sebagaimana telah dijelaskan di awal, merupakan essensi dari penegakkan hukum itu sendiri.

\section{E. Manahkah yang Dilarang, Penyampaian Gagasan ataukah Perbuatan?}

Secara tekstual, terdapat perbedaan yang mendasar antara Pasal 219 RKUHP 2015 dengan Pasal 212 RKUHP 2015. Pasal 219 RKUHP 2015 menekankan pada kegiatan 'menyebarkan dan mengembangkan', sedangkan pada Pasal 212 RKUHP 2015 lebih menekankan pada kegiatan 'menyatakan keinginannya'.Pasal 219 masih memiliki nuansa akademik, namun Pasal 212 sangat menunjukkan suatu intensi kesadaran subjektif terhadap pemahaman yang dimiliki atas suatu ideologi. Kedua kegiatan

\footnotetext{
Padmo Wahyono, Pembangunan Hukum di Indonesia, Jakarta: IND-HILL-Co, 1989, hlm. 15-16.

38 R. Achmad S. Soema di Pradja, Pengertian Serta Sifatnya Melawan Hukum Bagi Terjadinya Tindak Pidana (Dihubungkan dengan Beberapa Putusan Mahkamah Agung), Bandung: Amrico, 1983, hlm. 15.
} 
tersebut baru dapat dikatakan sebagai suatu perbuatan pidana ketika secara sengaja dan melawan hukum bertujuan untuk mengganti Pancasila sebagai dasar negara di muka umum. Kegiatan-kegiatan tersebut harus secara tegas dinyatakan bahwa memang demikian keinginannya. Jika dikaitkan dengan proses pembuktian, niat dan unsur secara melawan hukum tidaklah dapat berdiri sendiri, namun harus dapat diverifikasi dengan tujuan. Oleh karena itu, harus diperoleh kegiatan-kegiatan yang secara tegas dinyatakan, baik lisan maupun tulisan, oleh orang yang diduga melanggar ketentuan tersebut dalam bentuk yang tidak mengandung multitafsir lagi.

Unsur'dengan sengaja' atau 'dengan maksud' dan unsur 'secara melawan hukum' pada Pasal 219 dan Pasal 212 RKUHP 2015 harus terdeskripsikan pada satu kegiatan yang, ketika orang lain yang membaca dan/atau mendengarkan, sudah terkandung tujuannya adalah mengganti atau meniadakan Pancasila. Permasalahannya adalah bagaimana dengan pengajaran dan pengembangan dalam kerangka akademis yang menurut Pasal 219 ayat (3) RKUHP 2015 tidak dapat dipidana? Apakah dapat dipersamakan antara 'ruang akademik' dengan 'di muka umum' (openbaar)? Naskah akademik dari RKUHP 2015 tersebut tidak memberikan penjelasan mengenai kedua istilah tersebut, sehingga perlu kembali kepada pemaknaan pada umumnya.

Pemaknaan 'di muka umum' (openbaar) memiliki kesamaan makna dengan istilah 'terang-terangan' (openlijk), ada pula yang menggunakan istilah 'di hadapan umum' (engelbrecht). Menurut Moeljatno, pengertian 'di muka umum' lebih sempit daripada 'terbuka' atau 'terang-terangan' karena terikat kepada tempat-tempat umum. Publik harus melihat atau mendengarnya perbuatan yang yang bersangkutan dari tempat umum, termasuk juga tempat yang biasanya tidak atau tidak selalu terbuka untuk umum, tapi yang mana umum ketika perbuatan dilakukan, boleh masuk sekalipun dengan membayar syarat lain. Syarat ini tidak perlu bagi openbaar atau openlijk. Di sini syaratnya hanya dapat dilihat atau didengar oleh publik, khalayak ramai tanpa batasan dari tempat umum. ${ }^{39}$

Sedangkan 'ruang akademik', secara spesifik Pasal 219 ayat (3) RKUHP 2015 menggunakan istilah 'kegiatan ilmiah', artinya kegiatan yang bersifat ilmiah tidak harus berada di dalam ruang-ruang kelas pada perkuliahan. Namun setiap kegiatan yang bersifat ilmiah akan memperoleh perlindungan hukum dari Pasal 219 ayat (3) RKUHP 2015 tersebut, bahkan kegiatan ilmiah yang diselenggarakan di depan publik sekalipun. Maka dapat dipertanyakan makna manakah yang bersifat superior dan makna manakah yang bersifat inferior? Apakah 'di muka umum' lebih superior daripada makna 'kegiatan ilmiah', ataukah sebaliknya?

Secara yuridis normatif, istilah 'di muka umum' memperoleh bentuknya yang positif melalui Pasal 1 angka 2 Undang-Undang Nomor 9 Tahun 1998 tentang Kemerdekaan Penyampaian Pendapat Di Muka Umum yang menegaskan: "Di muka umum adalah dihadapan orang banyak, atau orang lain termasuk juga di tempat yang dapat didatangi dan atau dilihat setiap orang." Berdasarkan hal tersebut, maka

Moeljatno, Kejahatan-Kejahatan Terhadap Ketertiban Umum, Jakarta: Bina Aksara, 1984, hlm. 12. 
ruang-ruang kelas dalam perkuliahan dapat dihilangkan dari makna 'kegiatan ilmiah', kemudian yang dapat dikategorikan kemudian adalah kegiatan ilmiah dalam bentuk seminar, workshop, diskusi-diskusi, dan sejenisnya yang memiliki sifat terbuka, sehingga masuk dalam konflik norma (antinomi norma) dengan Pasal 219 (1) RKUHP 2015 tersebut.

Kondisi yang menarik dikaji adalah ketika seorang pemateri berdasarkan keilmuannya menyampaikan pandangan 'mengubah' Pancasila. Pemateri tersebut dalam ruang publik yang bersifat ilmiah dapat diklasifikasikan tidak memiliki unsur 'secara melawan hukum', oleh karena secara tegas memperoleh haknya berdasarkan undangan dari panitia penyelenggara. Dalam pendapat yang dikemukakan oleh Moeljatno, salah satu unsur yang wajib dipenuhi adalah 'sifat melawan hukum'40 Maka ketika seseorang menuangkan pemikirannya berdasarkan keilmuannya, apakah dapat diklasifikasikan sebagai perbuatan yang melawan hukum? Oleh karena berdasarkan kesadaran dan rasionalitas yang mengacu kepada teori-teori yang dipahaminya, seseorang akan dapat berpendapat berbeda, sehingga tidaklah mungkin hasil pemikiran ilmiah dapat diklasifikan sebagai suatu perbuatan melawan hukum dalam Hukum Pidana (wederrechtelijk).

Ditegaskan oleh Andi Zainal Abidin bahwa salah satu unsur esensial delik adalah sifat melawan hukum (wederrechtelijk) yang dinyatakan secara tegas atau tidak dalam suatu pasal undang-undang pidana, karena alangkah janggalnya apabila seseorang dipidana ketika melakukan perbuatan yang tidak melawan hukum. ${ }^{41}$ Sementara Roeslan Saleh mengatakan tidak ada artinya mempidana sesuatu yang tidak melawan hukum. ${ }^{42}$ Dalam hal ini, ketiadaan unsur 'melawan hukum' tersebut merupakan alasan pembenar.

Sedangkan berkaitan dengan unsur kesalahan diatur secara berbeda, yang mana pada Pasal 219 ayat (1) RKUHP 2015 menggunakan unsur 'dengan maksud' (Opzet als Oogmerk) dan Pasal 212 ayat (1) RKUHP 2015 menggunakan unsur 'menyatakan keinginan' artinya memiliki tujuan, yang dalam ranah doktrin Teori Kesalahan disebut pula 'dengan maksud' atau 'dengan tujuan' (Opzet als Oogmerk). Maka pertanyaan yang sama dapat diajukan, yakni apakah seseorang yang berpikir secara ilmiah berdasarkan kaidah-kaidah IImu Hukum adalah merupakan kesalahan? Bagaimana mengategorikan suatu pemikiran ilmiah adalah sebuah kesalahan?

Dengan demikian, pemateri atau pembicara dapat lepas dari jeratan Pasal 219 ayat (1) RKUHP 2015 dan Pasal 212 ayat (1) RKUHP 2015. Namun demikian, apabila diperhatikan rumusan delik pada Pasal 219 ayat (2) jo. Pasal 212 ayat (2) RKUHP 2015 yang memuat suatu klasifikasi akibat dari perbuatan pidana dapat dikenakan ancaman pidana penjara berdasarkan klasifikasinya. Terpenuhinya unsur 'melawan hukum' menjadikan seseorang wajib mempertanggungjawabankan perbuatannya. Sedangkan tidak terpenuhinya unsur 'melawan hukum' dan unsur 'dengan

\footnotetext{
Moeljatno, Asas-Asas Hukum Pidana, Jakarta: Rineka Cipta, 2002, hlm. 164.

Andi Zainal Abidin Farid, Hukum Pidana I, Jakarta: Sinar Grafika, 2007, hlm. 47.

Roeslan Saleh, Op.cit., hlm. 1.
} 
maksud' memunculkan alasan peniadaan pidana yaitu rechtsvaardigingsgrond (alasan pembenar) dan schuldduitsluitingsgrond (alasan pemaaf). Perlu dipahami bahwa alasan peniadaan pidana yang dimaksud adalah hilangnya kemampuan bertanggungjawab dari pemateri atau pembicara, sedangkan perbuatannya sendiri masih tetap merupakan perbuatan pidana. Artinya, perbuatannya dibenarkan dan dimaafkan karena alasan keilmiahan namun tidak dapat dipidana.

Namun demikian, pada Pasal 212 ayat (2) jo. Pasal 219 ayat (2) RKUHP 2015 merupakan perumusan suatu akibat dari perbuatan pada Pasal 212 ayat (1) jo. Pasal 219 ayat (1) RKUHP 2015. Perancang RKUHP 2015 telah menggeser dari 'dengan maksud' (Opzet als Oogmerk) menjadi unsur 'kesengajaan dengan kemungkinan' (Dolus eventualis, mogelijkeheidsbewustzijn). Menurut Wirjono Prodjodikoro, dolus eventualis menjelaskan bahwa apabila dalam gagasan si pelaku hanya ada bayangan kemungkinan belaka akan terjadi akibat yang bersangkutan tanpa dituju, maka harus ditinjau sendainya ada bayangan kepastian, tidak hanya kemungkinan, maka apakah perbuatan tersebut akan dilakukan oleh si pelaku. Apabila ini terjadi, maka dapat dikatakan bahwa kalau perlu, akibat yang terang tidak dikehendaki dan hanya mungkin akan terjadi itu akan dipikul pertanggungjawabannya oleh si pelaku jika akibat kemudian toh terjadi. ${ }^{43}$ Sehingga unsur ini bukan hanya akan sangat berkaitan dengan style dari pemateri atau pembicara dalam menyampaikan gagasan atau idenya yang bersifat ilmiah tersebut, namun berkaitan pula dengan daya intelektualitas pendengarnya. Sehingga pada akhirnya, pertanggungjawaban pidana melalui Pasal 212 ayat (2) jo. Pasal 219 ayat (2) RKUHP 2015 lebih mirip dengan vicarious liability.

Pasal 212 ayat (2) jo. Pasal 219 ayat (2) RKUHP 2015, dapat dikatakan sebagai suatu perumusan delik yang mengandung ketidakjelasan unsur. Perancang rumusan tersebut tidak secara jelas membedakan unsur-unsur mana yang merupakan hasil olah pemikiran akal budi yang merupakan ilmu pengetahuan dengan unsur-unsur dari perbuatan yang dapat dianggap sebagai perbuatan tercela untuk diklasifikasikan sebagai suatu perbuatan pidana.

\section{F. Penutup}

Indonesia berupaya menjaga Pancasila sebagai dasar negara namun megabaikan parameter-parameter ilmiah yang umum berlaku. Sejarah hitam masa lalu telah memblokade perkembangan pemikiran-pemikiran yang seharusnya. Apabila mengacu kepada konsep bahwa Pancasila adalah ideologi terbuka, justru untuk memperkuat pemahaman terhadap Pancasila sebagai ideologi bangsa. Hal yang seringkali terlupakan bahwa Pancasila bukan hanya sekedar ideologi, namun pula falsafah hidup bangsa yang hidup dan berkembang secara dinamis di dalam masyarakat. Sedangkan diskursus mengenai peraturan perundang-undangan selalu meliputi nuansa filosofis dan sosiologis. Hal ini yang menjadi keanehan, dimana

43 Wirjono Prodjodikoro, Asas-Asas Hukum Pidana Indonesia, Bandung: Refika Aditama, 2003, hlm. 44. 
suatu rumusan pasal tidak berasal dari pembahasan secara disiplin ilmu hukum (filsafat hukum-teori hukum- ilmu hukum), namun dirumuskan berdasarkan kajian politik yang memanfaatkan ilmu hukum dogmatis - minus filsafat.

Secara pribadi, Penulis sepakat bahwa pasal ideologi perlu diatur dalam RKUHP mengingat pengalaman sejarah masa lalu, namun demikian, pengaturan tersebut perlu pula dilakukan upaya pendistilasian hingga pada bentuk yang sangat konkret. Oleh karena ketika berbicara masalah ideologi, maka hal tersebut memuat tingkat abstraksi yang sangat tinggi dan tidak akan mampu dijangkau oleh penegakpenegak hukum yang memiliki kemampuan standar minimal ilmu hukum, melalui pengalaman praktik hukum Penulis, cukup meragukan. Ketidaksepahaman antara penegak hukum, khususnya penyidik dan jaksa dengan kuasa hukum, seringkali dibenturkan dengan pernyataan 'silakan dibuktikan dalam persidangan'.

$\mathrm{Hal}$ ini pula memiliki pengaruh dengan filsafat pemidanaan yang diakomodir oleh Pancasila, dari segi pemahaman para penegak hukum. Adalah yang sudah hampir bisa dipastikan melalui pengalaman praktik dan akademik, tidaklah dikuasai dengan baik oleh penegak hukum yang masih terjebak oleh paradigma positivisme hukum. Dengan demikian, perumusan dan perancangan terhadap Pasal 212 ayat (2) jo. Pasal 219 ayat (2) RKUHP 2015 hanya akan memunculkan tindakan hukum yang arbitrer dan absolut dari aparat penegak hukum.

\section{Daftar Pustaka}

\section{Buku}

Achmad Ali, Keterpurukan Hukum di Indonesia Penyebab dan Solusinya, Ghalia Indonesia, Bogor, 2005.

Andi Zainal Abidin Farid, Hukum Pidana I, Sinar Grafika, Jakarta, 2007.

Barda Nawawi Arief, Beberapa Aspek Kebijakan Penegakan dan Pengembangan Hukum Pidana, Bandung: Citra Aditya Bakti, 1998, hlm. 133 Pembangunan Sistem Hukum Nasional (Indonesia), Badan

Penerbit Universitas Diponegoro, Semarang, 2012.

, RUU KUHP Baru: Sebuah Restrukturisasi/Rekonstruksi

Sistem Hukum Pidana Indonesia, Badan Penerbit Universitas Diponegoro, Semarang, 2012.

Bernard Arief Sidharta, IImu Hukum Indonesia: Upaya Pengembangan IImu Hukum Sistematik Yang Responsif Terhadap Perubahan Masyarakat, Genta Publishing, Yogyakarta, 2013.

CFG. Sunaryati Hartono, Politik Hukum Menuju Satu Sistem Hukum Nasional, Alumni, Bandung, 1991.

Djoko Prakoso, Masalah Pemberian Pidana Dalam Teori dan Praktek Peradilan, Ghalia Indonesia, Jakarta, 1984.

Dwidja Priyatno, Kebijakan Legislatif tentang Sistem Pertanggungjawaban Pidana Korporasi di Indonesia, CV. Utomo, Bandung, 2004.

E. Sumaryono, Hermeneutik: Sebuah Metode Filsafat, Kanisius, Yogyakarta, 1999. 
E. Y. Kanter dan S. R. Sianturi, Asas-Asas Hukum Pidana di Indonesia dan Penerapannya, Storia Grafika, Jakarta, 2012.

Haryono, Ideologi Pancasila: Roh Progresif Nasionalisme Indonesia, Instrans Publishing, Malang, 2014.

Jan Remmelink, Hukum Pidana: Komentar atas Pasal-Pasal Terpenting dari KUHP Belanda dan Padanannya dalam KUHP Indonesia, Gramedia, Jakarta, 2003.

,Pengantar Hukum Pidana Materiil 1, Maharsa Publishing, Yogyakarta, 2014.

Komariah Emong Sapardjaja, Ajaran Sifat Melawan Hukum Materiel Dalam Hukum Pidana Indonesia, Alumni, Bandung, 2002.

Kusnu Goesniadhie, Harmonisasi Hukum Dalam Perspektif Perundang-Undangan (Lex Spesialis Suatu Masalah), JP Books, Surabaya, 2006.

M. Sholehuddin, Sistem Sanksi Dalam Hukum Pidana: Ide Dasar Double Track System \& Implementasinya, RajaGrafindo Persada, Jakarta, 2003.

Aksara, Jakarta, 1984.

Muladi dan Barda Nawawi Arief, Teori-Teori dan Kebijakan Pidana, Alumni, Bandung, 2005.

Padmo Wahyono, Pembangunan Hukum di Indonesia, IND-HILL-Co, Jakarta, 1989.

R. Achmad S. Soema di Pradja, Pengertian Serta Sifatnya Melawan Hukum Bagi Terjadinya Tindak Pidana (Dihubungkan dengan Beberapa Putusan Mahkamah Agung), Amrico, Bandung, 1983.

Roeslan Saleh, Sifat Melawan Hukum Perbuatan Pidana, Aksara Baru, Jakarta, 1987. Satijipto Rahardjo, Hukum, Masyarakat, dan Pembangunan, Alumni, Bandung, 1980. Slamet Sutrisno, Filsafat dan Ideologi Pancasila, Penerbit Andi, Yogyakarta, 2006.

Soerjono Soekanto, Faktor-Faktor yang Mempengaruhi Penegakan Hukum, Rajawali Press, Jakarta, 2012.

Sudarto, Pembaharuan Hukum Pidana di Indonesia, Bina Cipta, Jakarta, 1986.

Widodo Dwi Putro, Kritik Terhadap Paradigma Positivisme Hukum, Genta Publishing, Yogyakarta, 2011.

Wirjono Prodjodikoro, Asas-Asas Hukum Pidana Indonesia, Refika Aditama, Bandung, 2003.

\section{Dokumen Lain}

Abdul Hakim Garuda Nusantara, "Mengkritisi RUU KUHPidana Dalam Perspektif HAM", Makalah dalam Focus Groups Discussion Pembaharuan KUHP yang bertema 'Melihat Politik Kodifikasi dalam Rancangan KUHP', yang diselenggarakan oleh Lembaga Studi dan Avokasi Masyarakat (ELSAM), Hotel Ibis Tamarin, Jakarta, 28 September 2006.

Ahmad Bahiej, "Pembaharuan Hukum Pidana Indonesia (Telaah atas Rancangan Kitab Undang-Undang Hukum Pidana Indonesia)", Makalah disampaikan pada kajian rutin Pusat Studi dan Konsultasi Hukum (PSKH) Fakultas Syari'ah IAIN 
Sunan Kalijaga Yogyakarta tanggal 29 Desember 2003.

Gijssels, Jan dan Mark van Hoecke, "Apakah Teori Hukum Itu?", diterjemahkan oleh Bernard Arief Sidharta], Penerbitan Tidak Berkala Nomor 3, Seri Dasar-Dasar IImu Hukum Nomor 3, Laboratorium Hukum Fakultas Hukum Universitas Katolik Parahyangan, Bandung, 2001.

Saaty, Thomas L., "Relative Measurement and Its Generalization Decison Making: Why Pairwise Comparations are Central in Mathematics for the Measurement of Intangible Factors: The Analytic Hierarchy/Network Process", Rec. R. Acad. Cien Serie A. Mat, Vol. 102 (2), 2008.

Supriyadi Widodo Eddyono dan Fajrimei A. Gofar, "Menelisik Pasal-Pasal Proteksi Negara dalam RUU-KUHP: Catatan Kritis terhadap Pasal-Pasal Tindak Pidana Ideologi, Penghinaan terhadap Martabat Presiden dan Wakil Presiden dan Penghinaan terhadap Pemerintah", Seri Position Paper Reformasi KUHP No. \#7/2007, Lembaga Studi dan Advokasi Masyarakat dan Aliansi Nasional Reformasi KUHP, Jakarta, 2007.

\section{Dokumen Hukum}

Undang-Undang Dasar 1945 sebelum amandemen ke-IV.

Undang-Undang Nomor 11/PNPS/1963 tentang Pemberantasan Kegiatan Subversi.

Undang-Undang Nomor 9 Tahun 1998 tentang Kemerdekaan Penyampaian Pendapat di Muka Umum.

Undang-Undang Nomor 26 Tahun 1999 tentang Pencabutan Undang-Undang Nomor 11/PNPS/1963 tentang Pemberantasan Kegiatan Subversi.

Undang-Undang Nomor 27 Tahun 1999 tentang Perubahan KUHP yang Berkaitan dengan Kejahatan terhadap Keamanan Negara.

Ketetapan Majelis Permusyawaratan Rakyat Sementara Nomor XXV/MPRS/1966 tanggal 5 Juli 1966 tentang Pembubaran Partai Komunis Indonesia, Pernyataan Sebagai Organisasi Terlarang Diseluruh Wilayah Negara Republik Indonesia dan Larangan Setiap Kegiatan untuk Menyebarkan atau Mengembangkan Faham atau Ajaran Komunisme/Marxisme-Leninisme.

Ketetapan Majelis Permusyawaratan Rakyat Nomor I/MPR/2003 tanggal 7 Agustus 2003 tentang Peninjauan Terhadap Materi dan Status Hukum Ketetapan Majelis Permusyawaratan Rakyat Sementara dan Ketetapan Majelis Permusyawaratan Rakyat Republik Indonesia Tahun 1960 Sampai Dengan Tahun 2002.

Kitab Undang-Undang Hukum Pidana.

Rancangan Kitab Undang-Undang Hukum Pidana 2015. 